\title{
23. LATE PLIOCENE TO HOLOCENE PALYNOSTRATIGRAPHY AT ODP SITE 645, BAFFIN BAY 1
}

\author{
A. de Vernal ${ }^{2}$ and P. J. Mudie ${ }^{3}$
}

\begin{abstract}
Significant changes in terrestrial and marine environments of Baffin Bay occurred throughout the late Pliocene to Holocene. Upper Pliocene and lowermost Pleistocene sediments contain abundant pollen and spores, which indicates the existence of open, coniferous, boreal forest to forest tundra in areas surrounding Baffin Bay. The late Pliocene-earliest Pleistocene also is characterized by relatively rich, dinoflagellate cyst and acritarch assemblages of boreal character, in which the dominance of Cymatiosphaera and Peridiniaceae may indicate neritic influx of sediments. In contrast, the late-early Pleistocene to Holocene interval is marked by a sparse terrestrial and marine palynoflora, with rare productive intervals. The general paucity of the Pleistocene palynoflora suggests low primary productivity, both on land and offshore, probably caused by cold, dry, high arctic conditions.
\end{abstract}

\section{INTRODUCTION}

Baffin Bay is a small, deep oceanic basin surrounded by the Canadian Arctic Archipelago, Greenland, and Baffin Island (Fig. 1). This bay forms a "transitional" basin between the Arctic Ocean and the Labrador Sea, which is a northwestern extension of the North Atlantic Ocean. At present, surface-water circulation in Baffin Bay consists of a large counterclockwise gyre having two main components: (1) the subarctic West Greenland Current, which flows northward through the Davis Strait, and (2) the Baffin Land Current, which flows southward and is fed by the overflow from the Arctic Ocean through the Canadian Archipelago channels. Baffin Bay is a strategic location for studying paleoclimatic, paleoceanographic, and glacial fluctuations that occurred in the high latitudes of the Northern Hemisphere during the late Cenozoic. The onset of ice-rafting, which is indicative of glacial activity, occurred at least $2.5 \mathrm{~m} . \mathrm{y}$. ago, and probably as early as $3.4 \mathrm{~m} . \mathrm{y}$. ago (Srivastava, Arthur, et al., 1987).

Late Pliocene to Holocene sediments recovered in Hole 645B $\left(70^{\circ} 27^{\prime} 43^{\prime \prime} \mathrm{N}, 64^{\circ} 39^{\prime} 26^{\prime \prime} \mathrm{W}\right.$; in a water depth of $\left.2001 \mathrm{~m}\right)$ were sampled at approximately $1.5-\mathrm{m}$ intervals for palynological analysis to reconstruct changes in surface-water conditions from the dinocyst record and to reconstruct the evolution of the terrestrial vegetation from the pollen and spore record.

\section{METHODS}

Samples were prepared for palynological analysis using the following techniques:

1. Measuring the sample volume (usually 5 to $10 \mathrm{~cm}^{3}$ ) by immersion in a graduated cylinder.

2. Spiking the sample with an aliquot volume $(1.00 \mathrm{~mL})$ of a calibrated Eucalyptus globulus suspension to provide quantitative estimates of palynomorph concentrations.

3. Sieving at 10 and $125 \mu \mathrm{m}$ with distilled water to eliminate fine and coarse particles.

4. Treating with cold $10 \% \mathrm{HCl}$ (until visible reaction ceased) to remove carbonates.

\footnotetext{
${ }^{1}$ Srivastava, S. P., Arthur, M., Clement, B., et al., 1989. Proc. ODP, Sci. Results, 105: College Station, TX (Ocean Drilling Program).

2 GEOTOP, Université de Québec à Montréal, C. P. 8888, Succ. "A," Montréal, Québec H3C 3P8, Canada.

3 Atlantic Geoscience Centre, Geological Survey of Canada, Box 1006, Dartmouth, Nova Scotia B2Y 4A2 Canada.
}

5. Dissolving silicate minerals by repeated hot $48 \% \mathrm{HF}$ treatment (1 to $12 \mathrm{hr}$ ).

6. Eliminating fluorosilicates formed during the $\mathrm{HF}$ treatment by hot $10 \% \mathrm{HCl}$ treatment $(15 \mathrm{~min})$.

7. Washing with distilled water and sieving at $10 \mu \mathrm{m}$ to clean the preparation.

8. Mounting the residual sample in glycerine gel on microscope slides.

Palynomophs were counted systematically for most samples. However, scanning without counts was done for several samples in the $\sim 170$ 0 -mbsf interval, which is almost barren of nonreworked palynomorphs. Concentrations (Table 1) were evaluated on the basis of the exotic markergrain method (Matthews, 1969). The suspension of Eucalyptus globulus (used as the source of marker grains) was calibrated by counting with a hemacytometer. The marker-grain method yields accurate results to approximately $10 \%-12 \%$ for a 0.95 confidence interval (de Vernal et al., 1987).

Lentin and Williams (1985) provided the dinoflagellate cyst nomenclature. We also refer to de Vernal and Mudie's study (this volume) that describes the Pliocene-Pleistocene palynostratigraphy of Labrador Sea Sites 646 and 647 and that reports systematic descriptions for dinocysts and acritarchs also found in Baffin Bay samples.

\section{LITHOSTRATIGRAPHY AND CHRONOSTRATIGRAPHY OF HOLE 645B}

Sediments at Site 645 were drilled with some difficulty, with an average percentage of sediment recovery of $60.2 \%$ at Hole 645B. The unusual firmness and coarseness of the sediments and the frequent occurrence of dropstones may account partly for this poor recovery. In general, upper Pliocene and Pleistocene sediments from Hole 645B are highly terrigenous, poorly sorted, rich in sand and gravel, and are characterized by poorly developed primary sedimentary structures. Two main lithologic units were distinguished (Srivastava, Arthur, et al., 1987).

Unit I (168.1-0 mbsf) consists of alternating beds of calcareous muddy sand and silty mud with dropstones. This unit is characterized by a high calcium carbonate content of detrital origin $(10 \%-50 \%)$. Sedimentation probably was controlled by ice-rafting, with transportation and outwash deposition from surrounding ice sheets also significant.

Unit II (320.4-168.1 mbsf) consists of silty mud, clayey silt, and silty clays with sparse dropstones. The carbonate content, all of detrital origin, varies from $5 \%$ to $20 \%$. We interpreted sedimentation and detrital supply as resulting from ice rafting and weak bottom currents.

Marine microfossils are sparse in sediments from Hole 645B: diatoms, radiolarians, and calcareous nannofossils are generally 


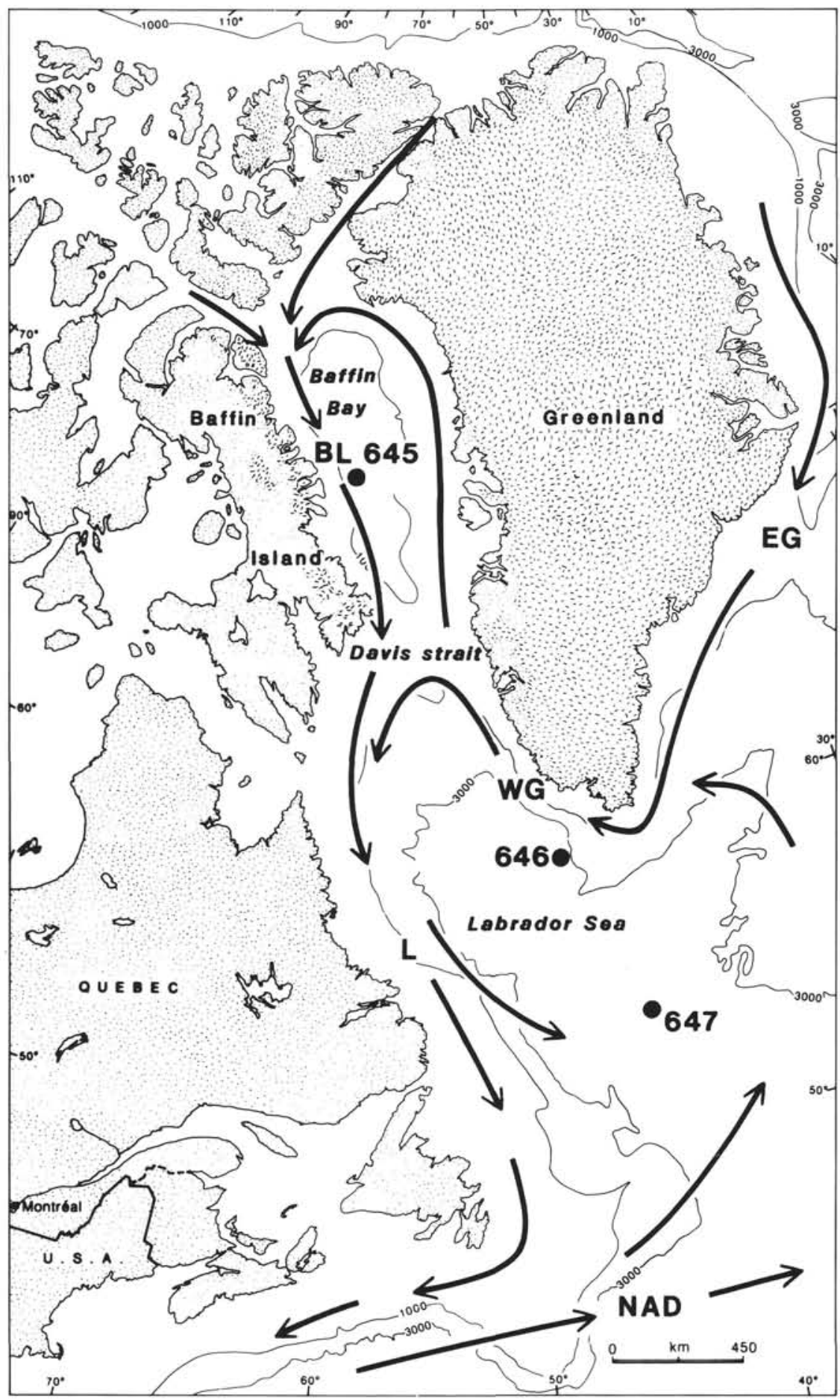

Figure 1. Location of ODP Sites 645,646 , and 647 in Baffin Bay and the Labrador Sea. Today's surface-water circulation is indicated by arrows: $N A D=$ North Atlantic Drift; $E G=$ East Greenland Current; $W G=$ West Greenland Current; $L=$ Labrador Current; $B L=$ Baffin Land Current.

absent; foraminifers and dinoflagellate cysts are rare. The paucity of the marine thanatocoenoses, in addition to possible reworking, made it difficult to establish a firm biostratigraphy. Moreover, the poor sediment recovery limits the usefulness of magnetostratigraphy. Nevertheless, a few paleomagnetic and biostratigraphic data suggest that the early/late Pleistocene and Pliocene/Pleistocene transitions are located at 94 and about 220 mbsf, respectively (Srivastava, Arthur, et al., 1987), with refer- ence to the Berggren et al. (1985) time scale. High sedimentation rates of about $13 \mathrm{~cm} / \mathrm{k}$.y. were estimated for Hole $645 \mathrm{~B}$.

\section{PALYNOLOGY}

Moderately well-preserved palynomorphs were observed in all samples analyzed. The palynomorph assemblages contain marine (dinocysts and acritarchs), terrestrial (pollen and Pteridophyte spores) and pre-Neogene reworked components. The 
Table 1. Palynomorph concentrations in analyzed samples from Hole 645B.

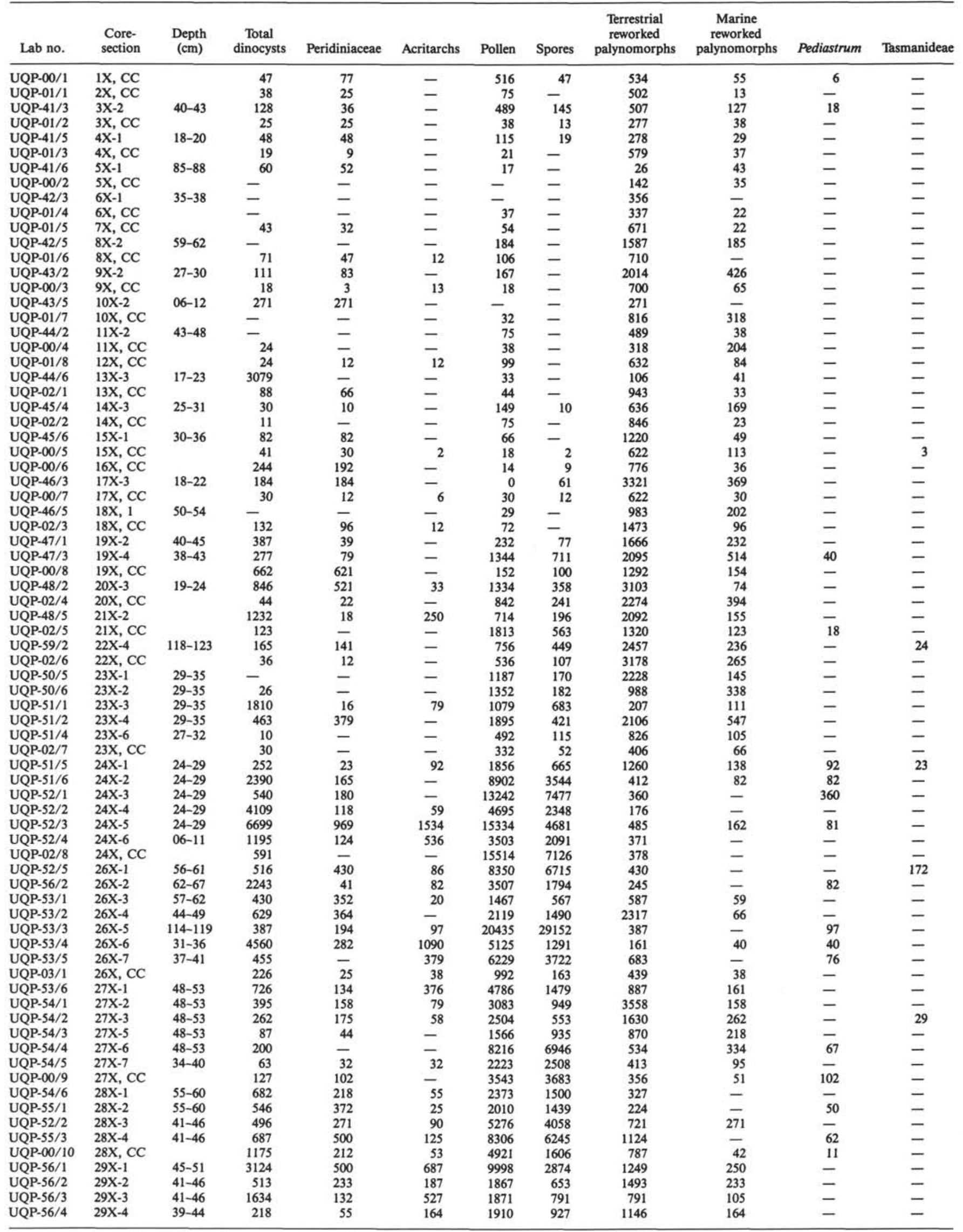


Table 1 (continued).

\begin{tabular}{|c|c|c|c|c|c|c|c|c|c|c|c|}
\hline Lab no. & $\begin{array}{l}\text { Core- } \\
\text { section }\end{array}$ & $\begin{array}{l}\text { Depth } \\
\text { (cm) }\end{array}$ & $\begin{array}{c}\text { Total } \\
\text { dinocysts }\end{array}$ & Peridiniaceae & Acritarchs & Pollen & Spores & $\begin{array}{c}\text { Terrestrial } \\
\text { reworked } \\
\text { palynomorphs }\end{array}$ & $\begin{array}{c}\text { Marine } \\
\text { reworked } \\
\text { palynomorphs }\end{array}$ & Pediastrum & Tasmanideae \\
\hline UQP-56/5 & $29 X-5$ & $38-43$ & 364 & 46 & 182 & 5834 & 4785 & 1231 & 137 & - & - \\
\hline UQP-56/6 & $29 \mathrm{X}-6$ & $85-10$ & 1106 & 369 & 184 & 16972 & 12636 & 737 & - & - & - \\
\hline UQP-03/2 & $29 \mathrm{X}, \mathrm{CC}$ & & 1763 & 43 & 559 & 7009 & 3354 & 817 & 43 & 43 & - \\
\hline UQP-57/1 & $30 \mathrm{X}-1$ & $42-46$ & 987 & 73 & 585 & 10638 & 4167 & 146 & 73 & - & - \\
\hline UQP-57/2 & $30 X-2$ & $20-24$ & 1067 & - & 278 & 2041 & 394 & 23 & - & - & - \\
\hline UQP-57/3 & $30 X-3$ & $131-135$ & 3903 & 149 & 2920 & 2086 & 983 & 89 & - & - & - \\
\hline UQP-57/4 & $30 X-4$ & $32-37$ & 4658 & 161 & 3759 & 4174 & 2583 & 323 & 46 & 46 & - \\
\hline UQP-57/5 & $30 \times-5$ & $34-39$ & 4792 & 80 & 1198 & 7867 & 4113 & - & 40 & - & - \\
\hline UQP-57/6 & $3-0 \times-6$ & $34-39$ & 2346 & 164 & 1146 & 11566 & 6056 & 164 & 55 & 55 & - \\
\hline UQP-58/1 & $30 \times-7$ & $30-35$ & 1173 & 51 & 663 & 7191 & 5049 & 151 & 51 & 51 & - \\
\hline UQP-03/3 & $30 \mathrm{X}, \mathrm{CC}$ & & 1531 & - & 265 & 1870 & 692 & 88 & - & - & - \\
\hline UQP-58/2 & $31 X-1$ & $40-45$ & 130 & - & 8 & 187 & 49 & 65 & 24 & - & - \\
\hline UQP- $58 / 3$ & $31 X-2$ & $40-45$ & 782 & 103 & 26 & 447 & 77 & 301 & 26 & - & - \\
\hline UQP-58/4 & $31 X-3$ & $40-45$ & 9181 & 116 & 5811 & 449 & 98 & 176 & 20 & - & - \\
\hline UQP- $58 / 5$ & $31 X-4$ & $40-45$ & 25 & 13 & - & 530 & 101 & 378 & 177 & - & - \\
\hline UQP-58/6 & $31 X-5$ & $40-45$ & 9 & 9 & 204 & 48 & 48 & 485 & - & - & \\
\hline UQP-03/4 & $31 \mathrm{X}, \mathrm{CC}$ & & 34 & - & - & 104 & 35 & 470 & 34 & - & - \\
\hline UQP-59/2 & $32 X-1$ & $105-110$ & 2864 & 15 & 121 & 558 & 196 & 30 & - & - & - \\
\hline UQP-59/3 & $32 X-3$ & $105-110$ & 1790 & - & - & 293 & 163 & 33 & 33 & - & - \\
\hline UQP-59/5 & $32 X-5$ & $105-110$ & 184 & 111 & - & 479 & 111 & 553 & 37 & - & - \\
\hline UQP-03/5 & $32 \mathrm{X}, \mathrm{CC}$ & & - & - & - & 103 & - & 615 & 114 & - & - \\
\hline
\end{tabular}

Note: "Total dynocysts" includes dinoflagellate cysts and acritarchs.

concentrations of these components vary considerably throughout the sequence (Fig. 2 and Table 1) and permit the delimitation of three intervals:

1. The lowermost interval (about 300-220 mbsf), of late Pliocene age, is characterized by an abundant terrestrial palynoflora ( 1,000 to 50,000 pollen grains and spores per cubic centimeter), frequently high concentrations of marine palynomorphs ( 0 to 9000 dinocysts and acritarchs per cubic centimeter), and common reworked palynomorphs $\left(0-3500 / \mathrm{cm}^{3}\right)$. This interval, marked by relatively high pollen and spore influxes (about $10-650 / \mathrm{cm}^{2}$ / yr), apparently corresponds to a period during which production of vegetation in terrestrial regions surrounding Baffin Bay was much higher than at present.

2. The interval from about 220 to $170 \mathrm{mbsf}$, interpreted as early Pleistocene, is characterized by abundant reworked palynomorphs $\left(>2000 / \mathrm{cm}^{3}\right)$ with moderate numbers of pollen and spores $\left(<2500 / \mathrm{cm}^{3}\right)$ and low dinocyst concentrations $(<1500 /$ $\left.\mathrm{cm}^{3}\right)$. The dominance of reworked palynomorphs in this interval requires that biostratigraphic and paleoenvironmental interpretations be made with care.

3. The uppermost interval (about $170-0 \mathrm{mbsf}$ ) is of Pleistocene age and is characterized by a sparse Quaternary palynoflora and by common occurrences of reworked pre-Neogene palynomorphs (about $500-2000 / \mathrm{cm}^{3}$ ). This interval reflects low primary productivity for arctic island vegetation and surface-water masses (Mudie and Short, 1985).

\section{Marine Palynoflora}

\section{Dinocyst and Acritarch Stratigraphy}

The dinoflagellate cyst and acritarch assemblages of the entire late Pliocene to Holocene interval are characterized by a low diversity (Fig. 3), especially when compared with those of the Labrador Sea Sites 646 and 647 (de Vernal and Mudie, this volume). Despite the general paucity of dinocyst and acritarch assemblages, a few biostratigraphic considerations should be noted.

1. The approximate Pliocene/Pleistocene transition is characterized by a decrease in the marine palynofloral diversity and, particularly, by the last common appearance of Cymatiosphaera sp. I, Batiacasphaera sp., and Operculodinium cf. crassum. In addition to these taxa, Brigantedinium sp., Tectatodinium sp. I, and Filisphera filifera show maximum abundances in the upper Pliocene sediments.

2. The lower part of the early Pleistocene is marked by the last occurrence of Filisphaera filifera (at about $150 \mathrm{mbsf}$ ). The last appearance of $F$. filifera, which is also recorded in lower Pleistocene sediments from other high latitude regions such as the Bering Sea (Bujak, 1984), Norwegian Sea (Mudie, in press), central North Atlantic (Mudie, 1986) and the Labrador Sea (de Vernal and Mudie, this volume), appears to be a good stratigraphic datum.

3. The upper part of the early Pleistocene through Holocene dinocyst assemblages consists of species that are common in modern sediments of Baffin Bay (Mudie and Short, 1985). The main taxa are Brigantedinium simplex, Operculodinium centrocarpum, Spiniferites elongatus, and Multispinula minuta.

\section{Paleoenvironmental Interpretation}

As shown in Figure 3, the vertical distribution and abundance of dinocyst and acritarch taxa are highly discontinuous. Some taxa, such as ?Cordosphaeridium sp. I, Impagidinium japonicum, and Achomosphaera ramulifera are common in only one or a few samples. The intermittent occurrence of dinocyst and acritarch taxa suggests frequently changing paleoenvironmental conditions in surface waters throughout the late Pliocene to Holocene. The epicontinental and relatively isolated location of Baffin Bay probably accounts for strong regional environmental responses to changes in climate or hydrologic regimes. Indeed, the much lower dinocyst diversity recorded in Baffin Bay sediments, compared with Labrador Sea sediments, points to more rigorous environmental conditions in Baffin Bay and to very limited exchanges between both basins during the late Pliocene to Holocene interval. A similar low diversity palynoflora also can be seen in upper Pliocene and Pleistocene sediments of the Norwegian Sea, which is partially isolated from the North Atlantic by the Iceland-Faroes Ridge (Mudie, in press).

The relatively high concentrations of dinocysts and acritarchs in the Pliocene sediments of Baffin Bay indicate a significant, although variable, meroplanktonic productivity that may reflect changes in phytoplankton production. Dinocysts represent the 


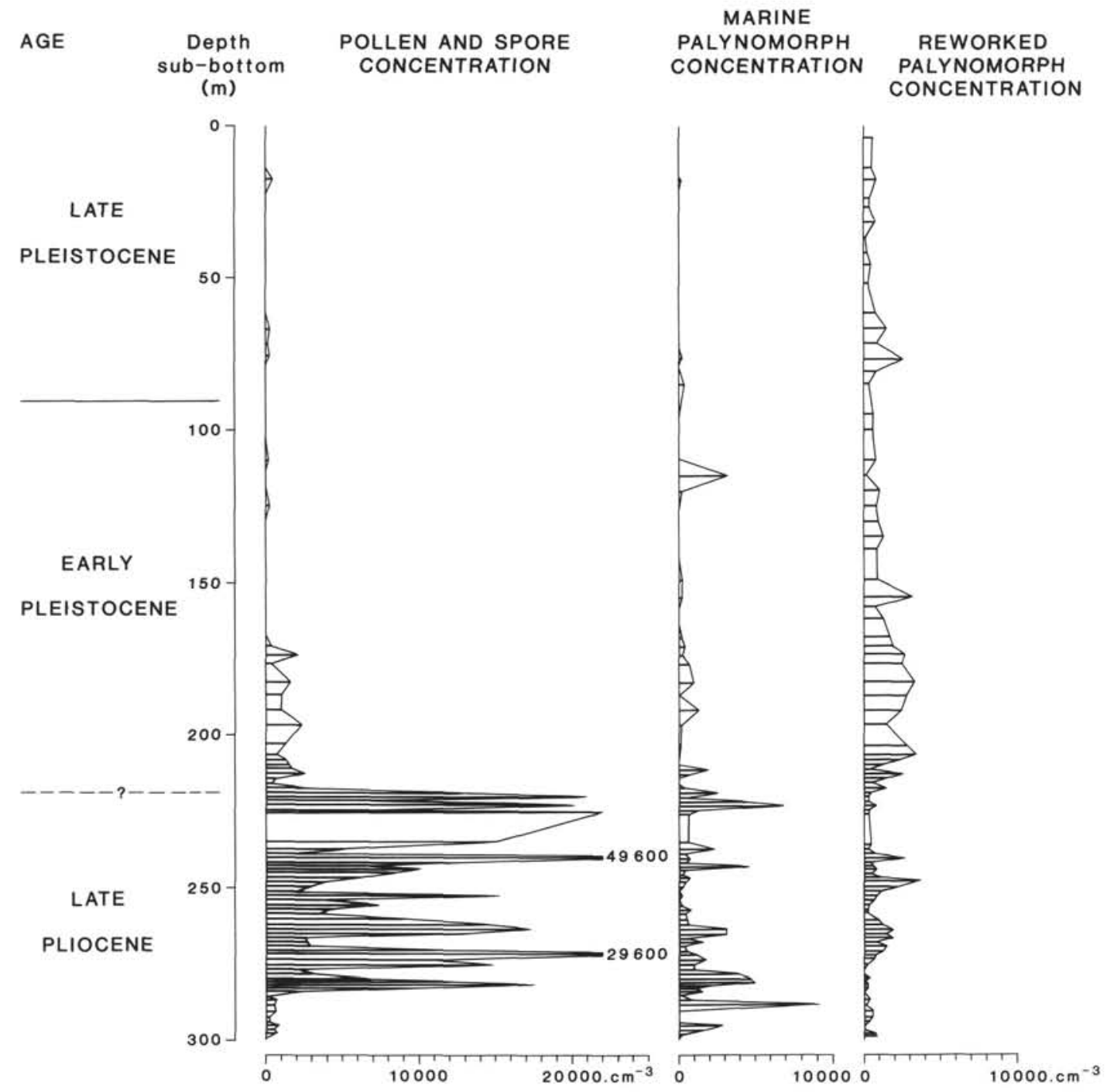

Figure 2. Palynomorph concentrations vs. depth at Hole 645B. Marine palynomorphs include dinocysts and acritarchs. Chronostratigraphy after Srivastava, Arthur, et al., (1987).

dormant stage before the reproduction of certain dinoflagellates (e.g., Wall and Dale, 1968) and the acritarch Cymatiosphaera probably constitutes the phycoma of Prasinophytae algae (Boalche and Parke, 1971; Tappan, 1980); hence, concentrations of dinoflagellate cysts and Cymatiosphaera are related to phytoplanktonic production. According to ecological considerations by Tappan (1980) and some fossil records (e.g., Takahashi, 1971; Wall et al., 1973; Al-Ameri, 1986), Cymatiosphaera may be associated with neritic environments. The common occurrence of peridinioid cysts, such as Brigantedinium sp., also suggests a neritic influence in the surface-water layer (e.g., Harland, 1983; Mudie and Short, 1985), and/or abundant dissolved nutrients (Duffield and Stein, 1986). The epicontinental character of the Baffin Bay basin probably favored high biogenic terrestrial influxes and, therefore, high nutrient influxes, which may explain neritic-type productivity despite relatively deep water masses. The species composition of the Pliocene dinocyst assemblages show a boreal character, which suggests the existence of subarctic or warmer conditions in surface waters. Filisphaera filifera, which generally dominates the assemblage, is a taxon reported exclusively from high-latitude regions, including the Arctic Ocean (Aksu and Mudie, 1985). However, surface-water conditions in Baffin Bay were probably episodically cool-temperate, as sug- gested by intermittent occurrence of taxa such as Achomosphaera ramulifera, Operculodinium cf. crassum, and Tectatodinium pellitum.

Most of the Pleistocene samples are characterized by low dinocyst concentrations, which indicates low meroplanktonic productivity compared to the Pliocene. The absence of diatoms and nannofossils in most Pleistocene samples (Srivastava, Arthur, et al., 1987) strongly suggests a low primary productivity in addition to high sedimentation rates. Rigorous environmental conditions similar to today's High Arctic (Mudie and Short, 1985 ) and the existence of an extensive sea-ice cover probably restricted the primary productivity during most of the Pleistocene. However, brief episodes of higher productivity are indicated by concentration curves, notably in high-resolution records (Mudie and Aksu, 1984; Mudie and Short, 1985; de Vernal et al., 1987; Hillaire-Marcel et al., this volume). These episodes are marked either by subarctic dinocyst assemblages dominated by Operculodinium centrocarpum and Spiniferites elongatus or by arctic assemblages dominated by Multispinula minuta and Brigantedinium simplex. The subarctic assemblages are associated with conditions similar to today's in central Baffin Bay and probably reflect the penetration of subarctic North Atlantic water through Davis Strait. The Multispinula minuta 


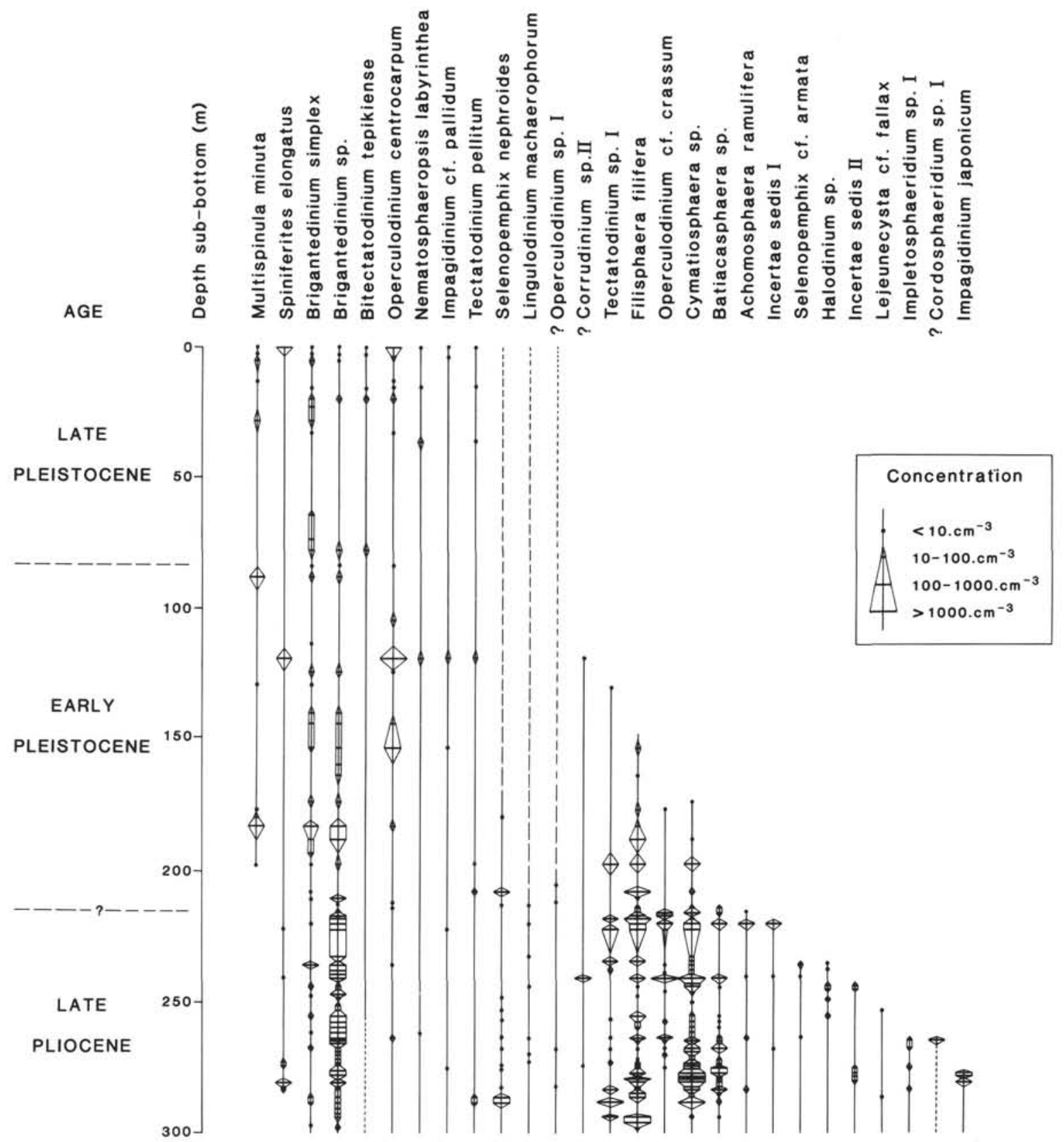

Figure 3. Stratigraphic range of dinoflagellate cysts and acritarchs in upper Pliocene to Holocene sediments of Site 645, including data from the high-resolution record in upper Pleistocene sediments (Hillaire-Marcel et al., this volume).

and Brigantedinium simplex assemblages are associated with Arctic Ocean margin conditions (Harland et al., 1980; Mudie and Mathiessen, 1988) and indicate relatively low salinity in surface waters ( $30 \%$; Mudie and Short, 1985). Such assemblages probably reflect significant dilution of surface waters from meltwater discharges. The dinocyst stratigraphy of Baffin Bay suggests that harsh, arctic-type conditions prevailed during most of the Pleistocene, with scattered brief warmer episodes marked either by the penetration of North Atlantic water or by large volumes of meltwater discharge.

\section{Terrestrial Palynoflora}

The lower part of the sequence in Hole 645B, and especially the upper Pliocene sediments, is characterized by abundant pollen and spores, with concentrations varying from 1,000 to 50,000 grains $/ \mathrm{cm}^{3}$. These are unusually high concentrations compared to other high latitude deep-sea sediments (e.g., Mudie, 1982), and they clearly indicate the epicontinental nature of the Baffin Bay basin. Within the $\sim 300-175$ mbsf interval, the richness of the terrestrial palynomorphs allowed us to count more than 100 pollen and spores in most slides, which resulted in the percentage diagram illustrated in Figure 4. Lower counts in Pleistocene samples were considered unsuitable for meaningful interpretation of percentage diagrams, although some late PleistoceneHolocene pollen diagrams were previously published (Mudie and Aksu, 1984; Mudie and Short, 1985; de Vernal et al., 1987).

Although a long time interval $(>2 \mathrm{Ma}$ ) is represented in the diagram of Figure 4, the pollen and spore assemblages appear relatively uniform in composition. The assemblages are largely dominated by Pinus, which is over-represented in deep-sea sediments off eastern Canada (Mudie, 1982) because its morphology is favorable for long-distance atmospheric and hydrologic 



Figure 4. Summary diagram of pollen and spore percentages from upper Pliocene and lowermost Pleistocene sediments of Site 645. Percentages are based on sums that include all the pollen grains and spores counted. The spectra reported in this diagram consist of sums higher than 100 individuals, in most cases; spectra with sums lower than 50 individuals are not reported. Because of the low diversity, 100 individuals may be considered statistically representative (Mudie, 1982). Here the genus Betula probably represents a shrub taxa, according to the small diameter $(<25 \mu \mathrm{m})$ of pollen grains (Richard, 1970; Usinger, 1975). Several taxa are grouped into genera or families to simplify the results: Lycopodium spores include mainly $L$. annotinum, $L$. selago-type, and $L$. clavatum-type; Alnus is mainly represented by $A$. crispa, although $A$. rugosa was occasionally observed. Other taxa are grouped into genera because of the uncertainty of the species identification.

transportation. Picea is moderately well represented among the tree taxa. The small percentages of Abies is highly significant, notably in the lowest part of the diagram: Abies is a tree that is under-represented by its pollen, even within the fir-forest domain (Richard, 1968), and generally not represented in surface marine sediments north of the Grand Banks (Mudie, 1982; Mudie and Short, 1985). Shrub pollen percentages, notably those of Betula, Alnus, and Ericaceae, are high. Herb pollen percentages are low but show a slight increase above the Pliocene/Pleistocene boundary at about 220 mbsf). Lycopodium, Selaginella, Polypodiaceae, and abundant Sphagnum spores are characteristic of the terrestrial palynomorph assemblages. These assemblages reflect influxes from relatively dense coniferous boreal forest to forest tundra vegetation. In addition, the high Sphagnum percentages indicate the existence of extensive peatlands in the source area. Such a vegetational cover may be associated with the existence of very humid, cool-temperate to subarctic climate. The high pollen concentrations indicate influxes from a nearby source, which strongly suggests that forested vegetation extended over Baffin Island and probably Greenland (Funder et al., 1985) during the late Pliocene and perhaps the earliest Pleistocene.
Despite the uniformity of the pollen and spore assemblage composition, fluctuations of percentages were recorded. These fluctuations may have been caused by changes in the vegetation, such as variations in the density of forest cover. The significant percentages of Abies in the lower one-half of the diagram strongly suggests the presence of fir in the forest community, confirming the existence of a cool-temperate climate for the arctic islands. The decrease of Abies and slight increase of herb percentages in the upper part of the diagram suggest an impoverishment of the vegetation, accompanied by opening of the forest cover. This change in the vegetation was probably related to a climatic cooling, from cool-temperate to subarctic conditions. Furthermore, the drastic decrease in palynomorph concentrations in the lowermost Pleistocene sediments suggests both a decrease in the vegetation density and increased aerial transport distance as a consequence of more remote forested-vegetation sources arising from a southward-migrating tree line in early Pleistocene.

The low pollen and spore concentrations recorded throughout most of the Pleistocene indicate low influxes, probably related to sparse vegetation cover or barren terrestrial areas surrounding Baffin Bay. Note, however, that the high-resolution record of upper Pleistocene sediments from Site 645 suggests that 
shrub tundra vegetation existed around Baffin Bay during an interglacial episode, which probably corresponds to the isotopic substage 5e (Hillaire-Marcel et al., this volume).

\section{Reworked Palynoflora}

A conspicuous feature of the Baffin Bay samples is the abundance of pre-Neogene reworked palynomorphs, which consist of both terrestrial (pollen and spore) and marine (dinocyst, acritarch) taxa.

The terrestrial palynoflora generally dominates. Trilete spores and bisaccate pollen grains are particularly abundant; angiosperm pollen grains also occur in low concentrations in most samples. The reworked terrestrial palynomorphs are characterized by a high degree of compression and a dark yellow to brownish color. The diagenetic alteration of the sporopollenin also can be distinguished by fluorescent microscopy. Because of this strong alteration, the structures of the exine or sporoderm are often indistinct; for example, the alveolar structure of gymnosperm saccae is faint. This strong alteration makes taxonomic identification difficult, particularly for trilete spores and bisaccate pollen grains. Cretaceous spores of the genera Cicatricosisporites, Appendicisporites, and Camarozonosporites were identified in several samples. Among the angiosperm reworked pollen grains, Triporopollenites is frequent; Tiliaepollenites, Caryapollenites, Alnipollenites, and Extratriporopollenites were occasionally observed.

Reworked dinocysts and acritarchs, notably Veryhachium, are present in most samples. Deflandrea spp., notably $D$. phosphoritica and Wetzeliella articulata, are frequent, which indicates some reworking from Paleogene strata; a few specimens of Phelodinium magnificum, Dinogymnium acuminatum, Chatangiella granulifera, Odontochitina sp., and Thalassiphora pelagica were also identified.

The reworked palynoflora generally reveals the erosion of Paleogene, Cretaceous, and older strata, which no doubt originate from the Canadian Arctic Achipelago, where sedimentary formations dominate. Glacial erosion and subsequent transportation by meltwater discharge or ice rafting are probably responsible for a large part of the reworked palynomorph content in sediments.

The reworked palynomorph concentrations vary in the lowest part of the Hole 645B record, possibly indicating fluctuations in the erosional intensity and glacial activity over arctic areas during the late Pliocene. Reworked palynomorphs are most abundant in the lowermost Pleistocene deposits, which suggests that erosion and/or glacial activity was very intense over arctic areas during this interval. In upper Pleistocene sediments, the concentrations of reworked palynomorphs remain high, although a slight decrease may distinguish the late Pleistocene. This trend may reflect a reduction of glacial activity in the arctic region throughout the Pleistocene. This interpretation is supported by the stratigraphy of Banks Island, which indicates that the most intense glaciation took place during the Matuyama paleomagnetic event (Vincent et al., 1984).

\section{DISCUSSION AND CONCLUSIONS}

The palynoflora of Hole 645B reveals that large changes took place both in the surface waters and in terrestrial environments of the Baffin Bay region during the late Pliocene to Holocene.

Throughout the late Pliocene, a moderately high meroplanktonic productivity is indicated by variable dinocyst and acritarch concentrations. The dinocyst assemblages reflect boreal, cool-temperate to subarctic conditions, while the dominance of Cymatiosphaera and peridinioid dinocysts indicates a neritic marine influence and/or high nutrient influx.

Pollen and spore concentrations of the upper Pliocene sediments indicate relatively high primary production in continental areas surrounding the Baffin Bay. The assemblages probably reflect the presence of relatively dense coniferous boreal forest and extensive peatlands, suggesting humid, cool-temperate to subarctic climatic conditions. During this same interval, deposition of ice-rafted debris shows that glaciation occurred in areas adjacent to Baffin Bay. Episodic glacial activity on the Canadian Arctic islands also may be indicated by the occurrence of reworked terrestrial palynomorphs, which may result from glacial erosion of the northern Canadian Arctic islands or from increased fluvial erosion during periods of high rainfall.

Although debatable, the existence of subarctic, or even cooltemperate, conditions in the Baffin Bay region is not incompatible with continental ice growth elsewhere in the arctic highlands. Indeed, the continental palynostratigraphy of southeastern Canada shows that such climatic conditions prevailed at the margin of the Laurentide ice-sheet during the middle Wisconsinan episode (de Vernal et al., 1986; de Vernal and HillaireMarcel, 1986). Furthermore, ice growth in the Arctic strongly depends on the transportation of humid air masses to highest latitudes, which is favored by the existence of cool-temperate open water areas in ocean basins, such as Baffin Bay. The existence of a humid and cool-temperate climate in subpolar regions probably contributed to high precipitation and possibly to ice accumulation in the arctic highlands during the late Pliocene. The large fluctuations of dinocyst, pollen, and reworked palynomorph concentrations in the upper Pliocene deposits may reflect cyclic glacial activity in the Canadian Arctic Archipelago, comparable to those recorded in southeastern Canada during the late Pleistocene.

Large-scale paleoenvironmental changes apparently occurred during the earliest Pleistocene. Decreases in the marine palynoflora diversity and concentrations suggest a decrease in primary productivity and probably reflect a change to more rigorous paleoenvironmental conditions. At the same time, the decrease in pollen concentrations, the decline of Abies, and the increase in percentage of herb pollens indicate an impoverishment of the regional vegetation and strongly suggest a southward displacement of the forest limits. Furthermore, the abundance of reworked palynomorphs indicates maximum erosion, probably from widespread glacial activity in the eastern Canadian Arctic.

Throughout the middle-early Pleistocene to Holocene interval, the sparse palynoflora suggests low primary productivity, both in surface water masses and in continental areas. With the exception of a few brief interglacial episodes, very harsh climatic conditions and extensive sea-ice cover probably prevailed over Baffin Bay.

\section{SYSTEMATIC DESCRIPTIONS}

Note: all palynological preparations and reference slides are housed at the Université du Québec à Montréal.

Division PYRRHOPHYTA Pascher 1914

Class DINOPHYCEAE Fritsch 1929

Order PERIDINIALES Haeckel 1894

Genus ACHOMOSPHAERA Evitt 1963

Achomosphaera ramulifera (Deflandre) Evitt, 1963

Genus BATIACASPHAERA Drugg 1970 Batiacasphaera sp.

Description. Cysts of Batiacasphaera sp. observed in sediments from Site 645 are spherical to subspherical and relatively small ( $\sim 25$ to $40 \mu \mathrm{m}$ ). When clearly seen, the apical archeopyle corresponds to the displacement of paraplates $1^{\prime}$ to $3^{\prime}$. Because of the usual poor preservation of the cysts from Hole $645 \mathrm{~B}$, we did not attempt to speciate the genus. Some of the cysts may be referable to B. sphaerica Stover 1977 (see de Vernal and Mudie, this volume). 
Genus BITECTATODINIUM Wilson 1973

Bitectadodinium tepikiense Wilson, 1973

Genus BRIGANTEDINIUM Reid 1977

Brigantedinium simplex (Wall, 1965) Reid, 1977

Brigantedinium sp.

Remarks. The archeopyle sutures cannot be distinguished on many cysts of Brigantedinium because of poor preservation, orientation, or folding. Thus, we often found it difficult to speciate the genus. Here, Brigantedinium sp. includes all round, brown Brigantedinium-type cysts, excluding $B$. simplex.

\section{Genus CORDOSPHAERIDIUM Cookson and Eisenack 1969 Cordosphaeridium sp. I}

(Pl. 1, Figs. 1-5)

Description. The cysts provisionally called ? Cordosphaeridium sp. I are subspherical ( 40 to $48 \mu \mathrm{m}$ in diameter; $\mathrm{N}=4$ ) with short ( 3 to $5 \mu \mathrm{m}$ high), broad, fibrous intratabular processes. Between processes, the periphragm is variably ornamented and fibrous (see Pl. 1, Figs. 2 and 5). In the optical section, the fibrous processes are crenulate (Pl. 1, Fig. 4). The cingular processes are often imperfectly developed and may be difficult to observe when the periphragm is coarsely ornamented. The precingular archeopyle of type $\mathrm{P}\left(3^{\prime \prime}\right)$ is free.

\section{Genus CORRUDINIUM Stover and Evitt 1978}

?Corrudinium sp. II of de Vernal and Mudie (this volume)

Description. The cysts are small (about $25 \mu \mathrm{m}$ in diameter), subspherical and characterized by a dense network of undulating crests that make it impossible to distinguish the paratabulation. The archeopyle is precingular, and the operculum is free. The field areas between crests are smooth. The taxonomic affinity of these cysts with the genus Corrudinium is uncertain since the accessory crests cannot be distinguished from the parasutural ones: the only clearly delineated parasutural feature is the paracingulum.

\section{Genus FILISPHAERA Bujak 1984 \\ Filisphaera filifera Bujak, 1984}

$$
\text { (Pl. 1, Fig. 8) }
$$

Genus IMPAGIDINIUM Stover and Evitt 1978

Impagidinium japonicum Matsuoka, 1983

Impagidinium $\mathrm{cf}$. pallidum Bujak, 1984

(Pl. 2, Figs. 1 and 2)

Description. The specimens from Baffin Bay and Labrador Sea sediments (de Vernal and Mudie, this volume) are similar to I. pallidum (Bujak, 1984) with respect to the thinness and transparency of the wall, the smoothness of the parasutural crest, and the frequent folding. Wellpreserved specimens from Holocene Labrador Sea sediments appear to have the following paratabulation: $3^{\prime}, 6^{\prime \prime}, 4 \mathrm{c}, 4^{\prime} "$ or $5^{\prime} ", 1^{\prime \prime} "$. The parasulcal region is clearly outlined by parasutural septa, but no sulcal paratabulation can be distinguished. The archeopyle is reduced, precingular, and formed by the loss of paraplate $3^{\prime \prime}$. The height of the parasutural septa is variable; the longest sutures exhibit the widest septa. The length of the polar axis varies from 58 to $78 \mu \mathrm{m}$, and the crest height ranges from 3 to $7 \mu \mathrm{m}(\mathrm{N}=14)$. In this paper, Impagidimium $\mathrm{cf}$. pallidum includes all morphotypes ranging from the common form to $I$. pallidum Bujak to more clearly tabulated Pleistocene-Holocene cystform.

\section{Genus IMPLETOSPHAERIDIUM Morgenroth 1966 Impletosphaeridium sp. I (PI. 1, Fig. 6)}

Remarks. Specimens of Impletosphaeridium sp. I observed in Baffin Bay and Labrador Sea sediments (de Vernal and Mudie, this volume), appears similar to Impletosphaeridium sp. I of Manum (1976). According to Matsuoka (1983), Impletosphaeridium sp. I Manum could belong to the species Reticulatosphaera stellata, which is characterized by intratabular processes with trifucate distal ends, apparently twiglike and connected by trabeculae. Specimens of Impletosphaeridium sp. I observed in Pliocene sediments from the Labrador Sea and Baffin Bay apparently cannot be attributed to Reticulatosphaera stellata Matsuoka, 1983 because of the lack of trabeculae joining the processes.
Genus LEJEUNECYSTA Artzner and Dorhofer 1978

Lejeunecysta cf. fallax (Morgenroth, 1966) Artzner and Dorhofer 1978

Remarks. The dinocysts attributed to Lejeunecysta cf. fallax show variations in the length of their equatorial and polar axis.

Genus LINGULODINIUM Wall 1967

Lingulodinium machaerophorum (Deflandre and Cookson, 1955) Wall, 1967

Occurrence. Appearance of this taxon in late Pliocene-Pleistocene sediments of Baffin Bay is very rare and may be due to reworking.

Genus MULTISPINULA Bradford 1975

Multispinula minuta Harland and Reid in Harland et al., 1980

Genus NEMATOSPHAEROPSIS Deflandre and Cookson, 1955

Nematosphaeropsis labyrinthea (Ostenfeld, 1903) Reid, 1974

Genus OPERCULODINIUM Wall 1967

Operculodinium centrocarpum (Deflandre and Cookson, 1955)

Wall, 1967

Operculodinium cf. crassum Harland, 1979

(Pl. 1, Fig. 7)

Remarks. Dinocysts assigned to Operculodinium cf. crassum are characterized by a relatively thick wall and short processes with bifid or flared tips. However, the cysts from Baffin Bay are very small $(\sim 35 \mu \mathrm{m})$ and usually bear very short and thin processes. They appear much more fragile than Operculodinium crassum Harland 1979. Thus, the species assignment is uncertain.

Operculodinium sp. I (de Vernal and Mudie, this volume)

Description. The cysts are subspherical, have no processes, and are characterized by microgranular ornamentation. The microgranules form an irregular and nontabular reticulation. The archeopyle is precingular of type $\mathrm{P}$ and constitutes the only expression of the paratabulation.

Genus SELENOPEMPHIX Benedek 1972

Selenopemphix nephroides Benedek, 1972, emend. Bujak, 1980 Selenopemphix cf. armata Bujak et al., 1980

Remarks. We included in this category the Selenopemphix cysts bearing spines, although these spines may have a variable morphology.

\section{Genus SPINIFERITES Mantell 1850}

Spiniferites elongatus Reid, 1974

Remarks. This taxon includes morphotypes of both Spiniferites elongatus and Spiniferites frigidus (Harland and Reid in Harland et al., 1980 ) and intergrades between these two species.

\section{Genus TECTATODINIUM Wall 1967 \\ Tectatodinium pellitum Wall 1967 \\ Tectatodinium sp. I of de Vernal and Mudie (this volume)}

(Pl. 1, Figs. 9-11)

Description. Tectatodinium sp. I is a spherical cyst characterized by a thick wall $(2.5-3.0 \mu \mathrm{m})$. The thin periphragm is supported by baculae forming a coarsely punctuated surface. The diameter varies from 36 to $45 \mu \mathrm{m}(\mathrm{N}=4)$. Tectatodinium sp. I could be a morphotype of Tectatodinium pellitum.

\section{Division CHLOROPHYTA Pascher 1914 \\ Class CHLOROPHYCEAE Kützing 1843 \\ Order CHLOROCHOCALES Pascher 1915 \\ Family HYDRODICTYACEAE Dumortier 1829 \\ Genus PEDIASTRUM Meyen 1829}

(Pl. 2, Fig. 12)

Occurrence. Colonies of the algae Pediastrum are frequently recorded in Pliocene-Pleistocene sediments of Baffin Bay (see Table 1). Most of them belong to the species Pediastrum boryanum (Turpin) Meneghini 1840, which is anubiquitous freshwater form (e.g., Prescott, 1953; Prescott and Vinyard, 1965). In deep-sea sediments, the occurrence of Pediastrum boryanum is probably related to fluvial or glaciofluvial runoff. 
Division PRASINOPHYTA Round 1971

Order PTEROSPERMALES Schiller 1925

Family TASMANIDACEAE Sommer 1956

Undifferentiated tasmanides are occasionally observed in sediments from Baffin Bay (see Table 1).

\author{
INCERTAE SEDIS \\ Group ACRITARCHA Evitt 1963 \\ Subgroup PTEROSPERMOPSIS Downie 1973 \\ Genus CYMATIOSPHAERA (Wetzel) Deflandre 1954 \\ Cymatiosphaera sp. I \\ (Pl. 2; Figs 6 and 7 and 10 and 11)
}

Remarks. In the Pliocene sediments of Baffin Bay, Cymatiosphaera sp. I is common and often dominates the marine palynomorph assemblages. Large variations in the overall size of the cysts (12 to $30 \mu \mathrm{m})$ and the height of intersecting crests (2 to $7 \mu \mathrm{m}$ ) were observed, which suggests that several species or morphotypes may be present.

According to phycologists, the fossil Cymatiosphaera represents the cyst stage or phycoma of green algae (Boalch and Parke, 1971; Tappan, 1980) that belong to the division Prasinophyta Round 1971, order Sperosphermatales Schiller 1925, and family Cymatiosphaeraceae Madler 1963.

\section{Incertae sedis I \\ (Pl. 2, Figs 8 and 9)}

Description. This taxon designates small acritarchs (12 to $25 \mu \mathrm{m}$ ) with a Pterospermopsis-type of wall, i.e., with a surface divided into fields by a reticulum of intersecting crests (Downie, 1973). Incertae sedis $\mathrm{I}$ is characterized by the presence of a few large fields and by wide (up to $6 \mu \mathrm{m})$, thick, massive crests. The crests are striate; in the optical section, the crest margins are straight to undulating or even spiny. The intersections between crests are nodal. A pylome with a subrectangular outline is sometimes present. According to its morphology, Incertae sedis I could be included in the genus Cymatiosphaera, although we prefer to retain it in a separate category here, because of its distinctive ornament. If this taxon is a species of Cymatiospaera, it probably represents the cyst stage of a Prasinophyte.

\section{Incertae sedis II}

(Pl. 2; Figs. 4 and 5)

Description. This taxon is probably a Pterospermopsis-type of acritarch. It is small (15 to $25 \mu \mathrm{m}$ ) and characterized by a dense network of broad cones and/or spines that are apparently connected along crests. A pylome with a subrectangular outline is frequently present.

\section{Group UNKNOWN \\ Genus HALODINIUM Bujak 1984}

$$
\text { (Pl. 2, Fig. 3) }
$$

Description. Specimens of Halodinium are relatively large (about 50 to $75 \mu \mathrm{m}$ in total diameter). They have a discoidal, thin, brownish endophragm with a semitransparent, smooth, irregular periphragm. Central pylome ( 15 to $20 \mu \mathrm{m}$ in diameter) is always free. The taxonomic affinity of Halodinium is unknown.

\section{ACKNOWLEDGMENTS}

Technical support was provided by C. Goyette and C. Lavergne for laboratory handling and by $\mathrm{M}$. Laithier for drawing. EMR-Canada support to ODP, financial assistance from NSERC-Canada (Grants A-9156 and CSP-Leg 105), FCAR Funds of Québec (Grant EQ-492), and the Geological Survey of Canada (Project 82-0044) were essential. We sincerely thank Monique Schuler, Rex Harland, and S. P. Srivastava for their critical and constructive review, which helped to improve the manuscript.

\section{REFERENCES}

Aksu, A. E., and Mudie, P. J. 1985. Magnetostratigraphy and palynology demonstrate at least 4 million years of Arctic Ocean sedimentation. Nature, 318:280-283.

Al-Ameri, T. K., 1986. Observations on the wall structure and excystment mechanism of acritarchs. J. Micropaleontol., 5:27-35.

Berggren, W. A., Kent, D. V., Flynn, J. J., and Van Couvering, J. A., 1985. Cenozoic geochronology. Geol. Soc. Am. Bull., 96:1407-1418.
Boalche, G. T., and Parke, M., 1971. The prasinophycean genera (Chorophyta) possibly related to fossil genera, in particular the genus Tasmanides. Proc. 2nd Plankton Conf., Roma, 1970, 1:99-105.

Bujak, J. P., 1984. Cenozoic dinoflagellate cysts and acritarchs from the Bering Sea and northern North Pacific, DSDP Leg 19. Micropaleontology, 30:180-212.

de Vernal, A., Causse, C. Hillaire-Marcel, C., Mott, R. J., and Occhietti, S., 1986. Palynostratigraphy and $\mathrm{Th} / \mathrm{U}$ ages of upper Pleistocene interglacial and interstadia deposits on Cape Breton Island, eastern Canada. Geology, 14:554-557.

de Vernal, A., and Hillaire-Marcel, C., 1986. Paléoenvironnements du Wisconsinien moyen dans l'est du Canada par l'analyse palynologique et isotopique de séquences sédimentaires continentales et océaniques: quelques aspects. Rev. Géol. Dyn. Géogr. Phys., 27:119-130.

de Vernal, A., Hillaire-Marcel, C., Aksu, A. E., and Mudie, P. J., 1987. Palynostratigraphy and chronostratigraphy of Baffin Bay deep-sea cores: climatostratigraphic implications. Palaeogeogr., Palaeoclimatol., Palaeoecol., 61:97-105.

de Vernal, A. Larouche, A., and Richard, P. J. H., 1987. Evaluation of the palynomorph concentrations: do the aliquot and the marker-grain methods yield comparable results? Pollen and Spores. 29:291-304.

de Vernal, A., Richard, P., and Jetté, H., 1983. Sur les effects de la technique de Lüber utilisée en analyse polinique pour éliminer la matière organique non-décomposée. Pollen and Spores, 25:541-548.

Downie, C. 1973. Observation on the nature of the acritarchs. Paleontology, 16:239-259.

Duffield, S. L., and Stein, J. A., 1987. Peridiniacean-dominated dinoflagellate cyst assemblages from the Miocene of the Gulf of Mexico shelf, offshore Louisiana. AASP Cont. Ser., 17:59-81.

Funder, S., Abrahamsen, N., Bennike, O., and Feyling-Hanssen, R. W., 1985. Forested Arctic: evidence from north Greenland. Geology, 13: 542-546.

Harland, R., 1979. Dinoflagellate biostratigraphy of Neogene and Quaternary sediment at Holes $400 / 400 \mathrm{~A}$ in the Bay of Biscay (Deep Sea Drilling Project Leg 48). In Montadert, L., Roberts, D. G., et al., Init. Repts. DSDP, 48: Washington (U.S. Govt. Printing Office), 531-545.

1983. Distribution maps of recent dinoflagellate cysts in bottom sediments from the North Atlantic Ocean and adjacent seas. Paleontology, 26:321-387.

Harland, R., Reid, P. C., Dobell, P., and Norris, G., 1980. Recent and sub-Recent dinoflagellate cysts from the Beaufort Sea, Canadian Arctic. Grana, 19:211-225.

Lentin, J. K., and Williams, G. L., 1985. Fossil dinoflagellates: Index to Genera and Species (1985 Ed.): Can. Tech. Rept. Hydrogr. and Ocean Sci., 60:1-45.

Manum, S. B., 1976. Dinocysts in Tertiary Norwegian-Greeland Sea sediments (Deep Sea Drilling Project Leg 38). In Talwani, M., Udintsev, G., et al., Init. Repts. DSDP, 38: Washington (U.S. Govt. Printing Office), 897-919.

Matsuoka, K., 1983. Late Cenozoic dinoflagellates and acritarchs in the Niigata district, Central Japan. Palaeontographica, Abt. B, 187:89154.

Matthews, J., 1969. The assessment of a method for the determination of absolute pollen frequencies. New Phytol. 68:161-166.

Mudie, P. J., 1980. Palynology of later Quaternary marine sediments. [Ph.D. dissert.]. Dalhousie University, Halifax.

1982. Pollen distribution in recent marine sediments, eastern Canada. Can. J. Earth Sci., 19:729-747.

, 1986. Palynology and dinoflagellate biostratigraphy of Deep Sea Drilling Project Leg 94, Sites 607 and 611, North Atlantic Ocean. In Ruddiman, W. F., Kidd, R. B., Thomas, E., et al., Init. Repts. DSDP, 94: Washington (U.S. Govt. Printing Office), 785-812.

1988. Palynology and dinocyst biostratigraphy of the late Miocene to Pleistocene, Norwegian Sea, ODP Leg 104, Sites 642 to 644. In Eldholm, O., Thiede, J., et al., Proc. ODP, Sci. Results, 104: College Station, TX (Ocean Drilling Program).

Mudie, P. J. and Aksu, A. E., 1984. Paleoclimate of Baffin Bay: a $300,000 \mathrm{yr}$ record of foraminifera, dinoflagellte and pollen. Nature, 312:630-634.

Mudie, P. J. and Mathiessen, J., 1988. Palynology of surface sediments and cores. In Thiede, J., and Shipboard Scientists, Initial Results of RV Polarstern Cruise ARKTIS IV//3. Rept. on Polar Res., 43:177185. 
Mudie, P. J. and Short, S. K., 1985. Marine palynology of Baffin Bay. In Andrews, J. T. (Ed.), Quaternary Environments, Eastern Canadian Arctic, Baffin Bay and Western Greenland: London (Allan \& Unwin) 263-308.

Prescott, G. W., 1953. Preliminary notes on the ecology of freshwater algae in the Arctic slope, Alaska, with description of some new species. Am. Midland Nat., 50:464-473.

Prescott, G. W., and Vinyard, W. C., 1965. Ecology of Alaskan freshwater algae V. Limnology and flora of Malipuk Lake. Trans. Am. Microscop. Soc., 84:427-478.

Richard, P. 1968. Un spectre pollinique type de la sapinière à bouleau blanc pour la forèt Montmorency. Nat. Can., 95:565-576.

1970. Atlas pollinique des arbres, et de quelques arbustes indigènes du Québec. Nat. Can., 97:1-34, 97-161, 241-306.

Srivastava, S. P., Arthur, M., et al., 1987. Proc. ODP, Init. Repts., 105: College Station, TX (Ocean Drilling Program).

Takahashi, K., 1971. Microfossils from the Pleistocene sediments of the Ariake Sea area, west Kyushu. Pal. Soc. Japan Trans. Proc., 81:1126.
Tappan, H., 1980. The Paleobiology of Plant Protists: San Francisco (Freeman).

Usinger, H., 1975. Pollenanalytische und stratigraphische untersuchungen an zwei Spatglazial-vorkommen in Schleswig-Holstein. Mitteilungen der arbeitsgemeinschaft Geobotanik in Schleswig-Holstein and Hamburg, 25.

Vincent, J.-S., Morris, W. A., and Occhietti, S., 1984. Glacial and nonglacial sediments of Matuyama paleomagnetic age on Banks Island, Canadian Arctic Archipelago. Geology, 12:139-142.

Wall, D., and Dale, B., 1968. Modern dinoflagellate cysts and evolution of the Peridiniales. Micropaleontology, 14:265-304.

Wall, D., Dale, B., and Harada, K., 1973. Description of new fossil dinoflagellates from the Late Quaternary of the Black Sea. Micropaleontology, 19:18-31

Date of initial receipt: 3 June 1987

Date of acceptance: 16 March 1988

Ms 105B-133 


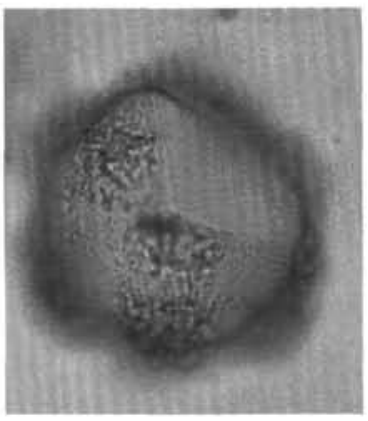

1

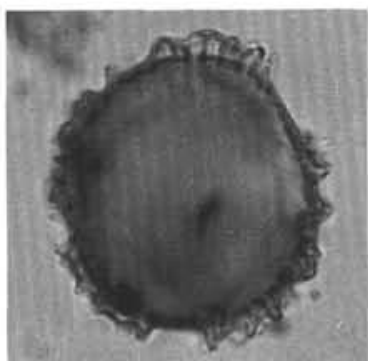

4

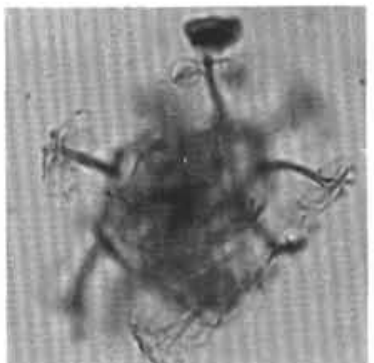

6



9



2

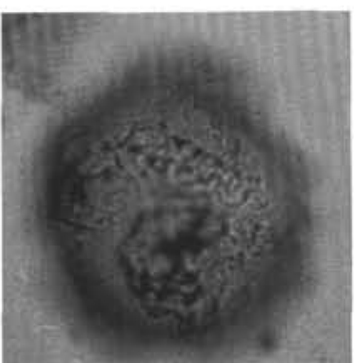

5

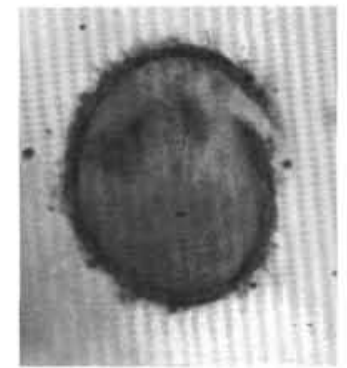

7

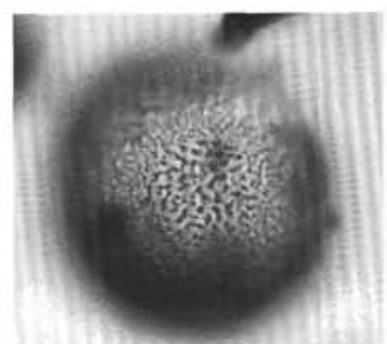

10

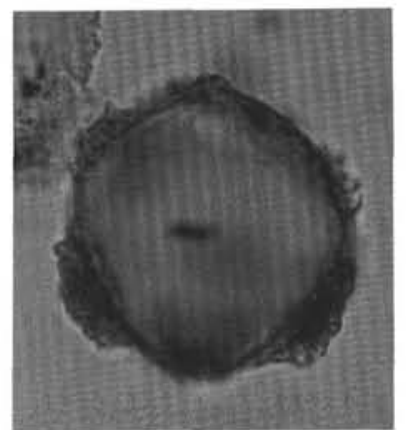

3



8

Plate 1. (All magnifications x 650; photographs taken in normal transmitted light on a Leitz Orthoplan microscope; UQP is the "Université du Québec à Montréal" reference number; the last alphanumeric code is the England Finder coordinate.) 1-3. ?Cordosphaeridium sp. I: (1) left lateral view with archeopyle in position 3", (2) right lateral surface, (3) optical section, Sample UQP-56/1', 105-645B-29X-1, 45-51 cm, P39/3. 4, 5. ?Cordosphaeridium sp. I: (4) optical section, (3) surface view, Sample UQP-56/1", 105-645B-29X-1, 45-51 cm, T51/1. 6. Impletosphaeridium sp. I: Sample UQP-56/1' ${ }^{\prime}$ 105-645B-29X-1, 45-51 cm, T25/3. 7. Operculodinium cf. crassum: optical section, Sample UQP-53/4', 105-645B-26X-6, 31-36 cm, P46/4. 9-11. Tectatodinium sp. I: (9) lateral view, (10) tangential surface, (11) optical section, Sample UQP-03/3", 105-645B-30X, CC, $\mathrm{P} 45 / \mathrm{O}$. 


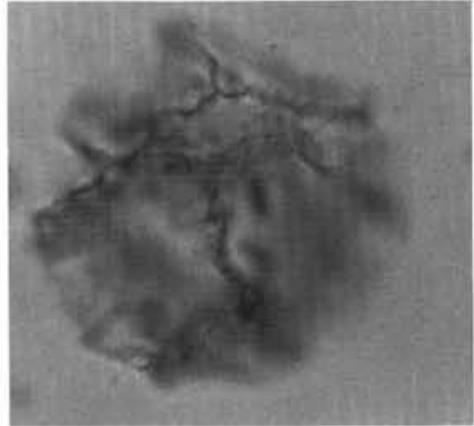

1

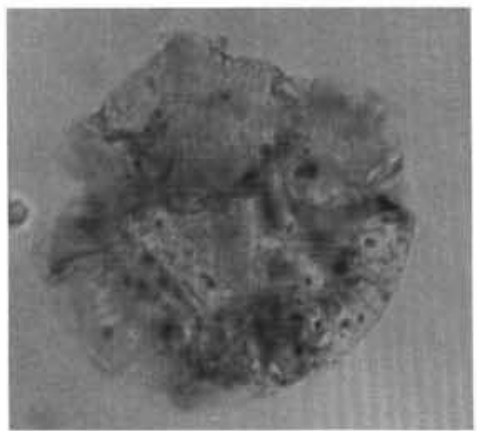

2

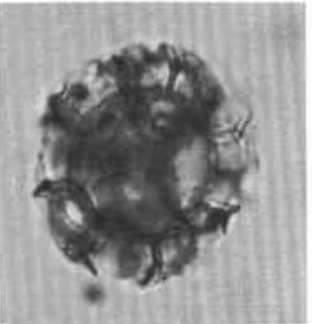

10

11



3

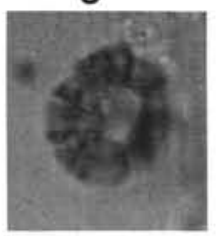

6

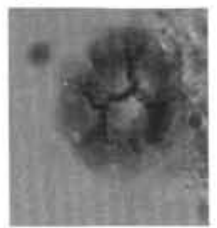

7



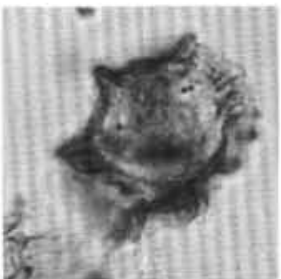

8

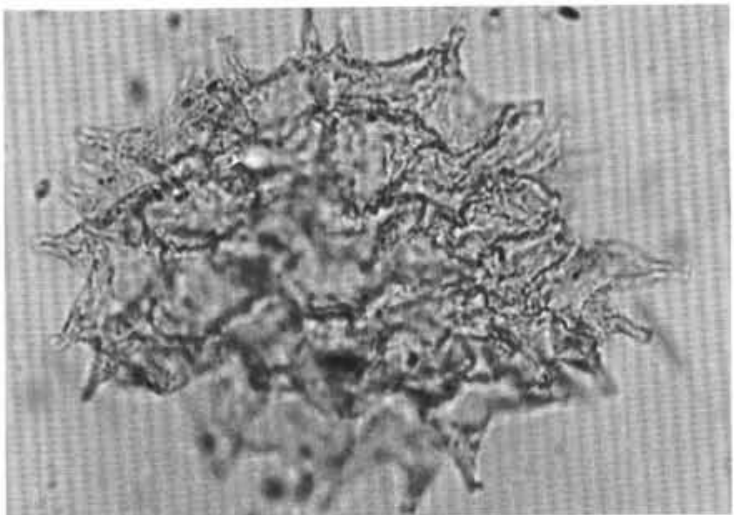

12

Plate 2. (All magnifications x 650; photographs taken in normal transmitted light on a Leitz Orthoplan microscope; UQP is the "Université du Québec à Montréal" reference number; the last alphanumeric code is the England Finder coordinate.) 1, 2. Impagidinium cf. pallidum: (1) right lateral surface, (2) left lateral view, Sample UQP-58/3', 105-645B-31X-2, 40-45 cm, H40/3. 3. Halodinium sp.: Sample 54/6', 105-645B-28X-1, 55-60 $\mathrm{cm}, \mathrm{U} 31 / 1$. 4, 5. Incertae sedis II: Sample UQP57/4, 105-645B-30X-4, 32-37 cm, P33/3. 6, 7. Cymatiosphaera sp. I, small specimen: Sample UQP57/4', 105-645B-30X-4, 32-37 cm, X56/4. 8, 9. Incertae sedis I: Sample UQP-108/5', 105-646B-31X-4, 27-32 cm, W24/1. 10, 11. Cymatiosphaera Sp. I, robust specimen: Sample UQP-58/4', 105-645B-31X-3, 40-45 cm, K34/1. 12. Pediastrum boryanum: Sample UQP-56/1', 105645B-29X-1, 45-51 cm, V30/3. 